\title{
Golding's Narrowed Attempts at Defining Human Nature in Lord of the Flies
}

\author{
* Rabia Khan, Lecturer \\ ** Sajjad Ahmad, Lecturer (Corresponding Author) \\ *** Ali Ammar, PhD Scholar
}

\begin{abstract}
This paper is an attempt to prove the assumption that William Golding is a failure who claims to have written his novel Lord of the Flies on the idea of human nature. He considers that he wrote about human nature in general, but he is a Western and has those ideas of being superior to other people. He takes all his characters from among the English boys. Not a single character who is shown as civilized belongs to a marginalized race. This act of Golding reveals his ethnocentric attitude. He does not bother to include a female character in this novel. All his characters are male. It shows his androcentric nature. Though he tries to put the evil like every man whenever he wants to show the brutality or savagery of a human, in the form of his chosen English boys, he portrays them as the hunters of Africa or paints them with mud. In doing so, he is affiliating savagery with the blacks and Indians. Thus, he propagates the same stereotypical concept of "Orients" as uncivilized and savages. Golding relies solely on the biological factors of human nature. He ignores to consider any social problem for the conflict of the two groups of boys. These social factors may include political system, religion, or Marxism. This research work has proved that Golding's self-critique of human nature in the novel is a failure on his part.
\end{abstract}

Keywords: Marginalized, androcentric, Lord of the Flies, Orient

Introduction

William Golding won the Nobel Prize for literature for his first novel Lord of the Flies. It was written in 1954 and was adopted into movies by two different directors. This novel was written in response to The Coral Island, another novel written by Ballantyne (Carey, 2012). This is the story of three English young boys, marooned on a tropical island. Golding was not satisfied with this novel, so he claimed that this novel does not seem true to his senses. Johnston (1980) asserts that the savagery of the natives has not been mentioned in the novel rather it came out of the outsiders who came there on the island by chance through the crash of the plane. Keeping in view this fact, Golding cast again those young boys from Ballantyne's novel The Coral Island but this time he brought them to a new marooned island. This must be a different island from that of Ballantyne. In Lord of the Flies, he judges human nature and the darkness of the human inner self from his point of view. Whatever he perceives from human nature has been depicted in this novel. He remained ignorant of those whose nature is under his observation. About whose nature he talks, is a question mark, which he never felt need to be answered. Golding's novel is a failure to become a great critique of human nature because he takes his experimental characters from a very small subgroup of the human population. We can scrutinize certain aspects due to which Golding's notion to examine human nature failed. These traits include ethnocentrism, androcentrism, stereotypical portrayal, and dependence on biological factors. Golding's assumption to be a critique of human nature is replaced by a critique of "Self" arrogance. When this critique is proved then it can also be proved as a critique of his idea being superior in his moral beliefs. In this case, we can also compare the American movie version of Lord of the Flies by Hook (1990) suggests that it was not a kind of war rather it was a fight against two groups out of which one group consisted of boys representing good and the other group comprised of boys representing bad. They were not struggling within themselves rather they were struggling among each other. But this view also seems to be an extremely simple one for the struggle tends to move outside

\footnotetext{
* Bacha Khan University, Charsadda Email: Raybaykhan@gmail.com

** Department of English, Bacha Khan University, Charsadda Email: lecturerbkuc@gmail.com

*** Air University Islamabad, Email: aracademy123@gmail.com
} 
of human existence when it already is inside a human being. Thus, Golding's critique disappears and what is left behind is a movie full of violent action.

\section{Research Objective and Questions}

The objective of this research is to explore and evaluate the objective of presenting in a specific manner human nature in the novel The Lord of Flies by William Golding. To achieve this objective, the researchers developed the research question of William Golding and have tried to present a narrower view of human nature related to the discussion of inherent good and evil. To extend the discussion of human nature as was presented by R. M. Ballantyne in The Coral Island (1857), Golding seems to be dissatisfied and attempts at moving beyond the limitations of human nature. But in his effort of expanding the horizons of knowledge about human nature, the issue is if he has entangled himself in another quagmire of a limited view of human psychology. If that is the case, the question also arises how this has been presented in the novel The Lord of Flies.

\section{Research Methodology}

It was qualitative research following the interpretivism paradigm. Textual analysis as a method for analyzing the novel was selected by applying the framework of analysis of Kathrine Belsey (2005) that she presented in her essay on textual analysis. The researchers have used extra-textual knowledge for the proper understanding and interpretation of the text as Belsey has stated. Belsey (2005) also argues that the task of the critic is to think deep not only into the surface meanings of the text but also in the inner implied meanings as to what the text implies, and what the intended readers or viewers are, what kind of effect the author wants to create, what person is used by the author and for what purpose and so on. The aim is to try to interpret and understand the inner motives and purposes of the author that he has implied in the text and has wanted to convey to his readers and audience. Merely written words are not the text for Belsey. All that which has some meanings either in oral, written, visual, or in any form is the part of the text and needs specific interpretation in a specific manner. In her essay, she takes up a painting as the text and conducts textual analysis. The first step of research work was the study of the texts and the related literature for deeper and better understanding. The second step was studying the texts to find the characteristics of the self in the postmodern and postpostmodern conditions. In the third step, various arguments were discussed in detail and an attempt would be made to arrive at logical generalizations. The last step was to conclude the discussion after achieving the research objective.

\section{Discussion}

Golding wrote Lord of the Flies_when World War II was about to be ended. This was a great event in history, and it compelled Europeans to have a deep look at their construction of themselves as 'civilized'. They used to consider themselves as civilized but they proved that they are not by taking an active part in the war. During this war, many killings occurred, which caused Golding to work on their concept of human nature and its condition. He consciously took a fertile tropical island as a setting for his story so that the boys would never engage in the struggle for their existence or survival. The boys are left to build their community on this tropical island, which may be compared to paradise. Here Hume (1983) aptly observed that the laws are required to man in a place where there is the availability of fewer things in the world, and where there are a lot of things for the man, there is no need for laws. A natural kind of harmony is developed inside man among each other. It is also because of this reason that there was a need for laws of security on the island for the children who had got divided into two groups signifying good and evil. Hobbes (1996, p. 10) is in contrast with this idea, who asserts that in the state of nature man is in a constant "war of all against all". Lord of the Flies is creditable because it challenges the stereotype of the pure white heart. It shows that savagery is not only present in the hearts of those 'others' whom we consider as our enemies but also it is present as all of 'us'. However, this novel does not succeed to be a comprehensive critique of human nature because it creates many assumptions, which are not even questioned. Fetterly (1986) points out that the criticism of a literary work can be changed and developed by women also because they are not open to initiate a dialogue, they are after all able to expand and open the dialogue. Golding assumes that the only way, to analyze human nature is to focus entirely on white males. This is the first and most awkward assumption made by him because it shows his both androcentric and ethnocentric attitudes. Most of the ideas presented by Golding are purely Western. He does not care for its validity as a universal idea though they are not accepted universally. Furthermore, he claims that he is diverting the stereotypical concept of savages, but he does not remain faithful to his words. 
Golding wants his readers to know that the boys have quit their social conditions and they have become savages that is the reason he comes back to the stereotypical representation of savages. Finally, Golding naturalizes behavior and draws a supposition that savagery is an inborn characteristic. Now we will analyze these assumptions and conclude that they limit this critique to a specific group of white males. Although these assumptions do not destroy Golding's critique of human nature, yet it plays an important role in its failure.

According to Rahman (1990), Golding's novel Lord of the Flies is "an anthropological study of human society" (p. 40). This view of Rahman is also the point of view of Golding in writing this novel but his assessment of human nature is not complete and sufficient to prove how it works. This drawback in Golding's novel is pointed out from the fact that he entirely depends on the behavior or nature of males ignoring any female character in his novel. This is his androcentric attitude to "use boys and men as the prototype for humankind" (p. 43). Spender (1985) in his essay Man Made Language asserts that the place of women in society has been that of subalterns and that they have been having no voice throughout human history. Spender only erased women from the speaking folk, but Golding goes a step further and excludes women from even consideration. He does not even bother to include them in the examination of human nature. It is not claimed that he must have given proper representation to females in his novel as other of his contemporary novelists did, but he should have thought about his theme about which he has written. Human nature is his subject, and he thinks that only males can be judged as the representatives of all humanity. What Golding is doing in this novel is just like checking a fruit in an apple tree and concluding that all the apples would be like this one. One apple cannot be the representative of all the fruits. It is true here in this novel that only males cannot be the representative of all the males and females. Golding is engaged in narcissism here i.e. doing the same thing, which he wants to criticize. There is no female character in this novel but a hint to female is given in the form of Piggy's aunt and a hunted pig. He took this pig as a female, which is killed as soon as it appears. We can observe the chanting of the hunter boys, "Kill the pig. Cut her throat. Spill her blood" (Golding, 1954, p. 69). Females are used only to enhance the savagery of the boys. Kinkead-Weeks (1984) points out the lust that starts emanating from the hunters when they are in the field and ready for their prey, particularly when the prey becomes the need of the hunters, the level of lust also increases.

Golding is not sincere with his motif in this novel as he claims to explore human nature. He negates a large population of humankind in the form of females. He places males as the superiors and prototypes. He seems to be ignorant of the fact that there is a big difference between the natures of males and females. If Golding is true and honest in his examination of human nature then he must have taken some female characters in this novel.

Hook (1990) made a change in his movie based on Lord of the Flies. He added sexual tension and the boys talking about girls. As mentioned, earlier Golding refers to only two female characters in Lord of the Flies but in this version of the movie, we come across a dialogue between Ralph and Jack while walking along the beach:

Ralph: "I don't know how things are going to work out. I mean what if someone gets sick?"

Jack: "Man, you gotta stop worrying so much, we've got it made: no parents, no teachers, no academy, and no girls. Of course, I wouldn't mind getting a little now and then."

Ralph: "Like you ever got any."

Jack: "Still, I wouldn't mind." They laugh and wrestle each other to the ground. (Golding, 1954, p. 23)

This dialogue is an insulting one towards females, but it is not included in the text rather Hook included it in its movie version. Golding might have added it in his text, but it is not his conscious ignorance or degradation of women.

Golding has examined human nature based on cultural examination. Mohan Ramanan (1987) claims that Lord of the Flies is mostly focusing on the newly developed ideologies and concepts that have been very much popular during his era of writing i.e. 1950s. He commented this based on Karl Marx's criticism of Darwin on ethnocentric grounds. Hubbard (1982) notices that there are contrasting views regarding the animal kingdom. Charles Darwin seems to assert that the animal kingdom develops civil society. This view is extended by the Hegelian point of civil society which is actually belonging to the animal kingdom but is also spiritual. 
Animals indeed struggle for survival and food against other animals. They want to get food and shelter and dominate each other. Golding refers to this thing only, but he ignores some other important issues like altruism. Golding shows the attitude of the boys to the island in the form of Judeo-Christian tradition, which marks that he, wants to show his religious attitudes in such a situation. He entirely depends on his religion in the reaction of the boys, "Eyes shining, mouths open, triumphant, they savored the right of domination" (Golding, 1954, p. 29) From here it also becomes clear that if Golding wanted to criticize the western culture and its effects on the innocent children, then this story again becomes a Eurocentric one for it focusses on Europe and its children. Because various cultures around the world seem to suggest that there is no need to surpass nature or even to be at a conflicting stance with nature, rather there is a need for the creation of harmony with nature. The same could also be observed in the wisdom of the sages of the Chinese culture. As a study of the human condition, Lord of the Flies_fails. Another ethnocentric attitude of Golding is there in the portrayal of his character. He uses only English boys for his novel. No other ethnic group boy is found in his novel. He wants to standardize English people. He attempts to explore human nature by only focusing on English boys. This attitude of Golding reveals that he is an ethnocentric writer who does not bother to show the nature of others. He has shown the English people as the standard and wants to conclude that others may be judged concerning them. He has done the same with English people as scientists have done with Carbon (C), an element, its atomic mass is taken as the standard and the atomic masses of other elements are to be found out by their comparison with it.

Hook made another change in his movie version of Lord of the Flies. In his movie version, he includes boys of other races as well. This movie depicts one black boy and one Hispanic as being a part of the marooned boys. This act of Hook empowers Golding's critique of human nature because other ethnic groups are also under experimentation. However, the black boy is depicted as being the prototypical savage. According to Ellen Seiter (1995), there are certain commercial principles for the depiction of blacks. She says that they are normally shown as a minority and they are not allowed speech on most occasions especially on particular occasions. Furthermore, the black children are also shown to be surrounded by groups of white children. All in all, whites are represented as dominating the blacks.

All the rules she describes are based on Hook's (1990) movie version. Tony is the only black boy who is on Jack's side from the beginning. He is shown as the right hand of Jack. He will be present at any place where there are violent hunters. He will always accompany Jack in his violent action. He acts as $2^{\text {nd }}$ in Command when Jack is not there.

In Coral Island, the boys are shown to maintain the standard of their civilization. They are well-knit enough, to show resistance to the threat of external evil. Lord of the Flies stands in complete contrast with this novel, as Golding has claimed himself. Lord of the Flies_reveals that evil does not come from the outside world or 'other' but is always there in the internal world of the English boys. Rahman (1990) argues that Golding wrote this novel to demonstrate that evil is within the human being. When jack confronts the pig for the first time, he cannot kill her because he is an English boy, both from his internal and external appearance. It is late in the novel to see 'good English' boys be the real beasts. Golding is using his unconscious stereotyping of the savage through which the evil he wanted to examine is externalized. Jack does not seem to be a savage in the first instant that is why he fails to kill the pig. Golding wants to say that savagery is only related to the blacks or the red. Here we can see his stereotyping:

Jack drew his knife again with a flourish (...) then the piglet tore loose from the creepers and scurried into the undergrowth. They were left looking at each other and the place of terror. Jack's face was white under the freckles. (Golding, 1954, p. 35)

When Jack is dressed like English and is shown acting in the manner of the English he is unable to bring out his brutal inside. But when he masks himself as primitives only then he becomes able to kill that pig.

Jack... knelt by the pool and opened the two large leaves that he carried. One of them contained white clay and the other red. By them lay a stick of charcoal brought down from the fire. Jack explained to Roger as he worked.

'They don't smell me. They see me, I think. Something pink under the trees. 'He smeared on the clay. 
(...) 'For hunting. Like in the war. You know- dazzle paint. Like things trying to look like something else-'He twisted in the urgency of telling. '- like moths on a tree trunk'. (Golding, 1954, p. 85)

Kinkead-Weeks and Ian Gregor (1984) defend this description of Golding in these words that Jack has been represented as showing aspects of civilized societies because Jack is shown to know the after of using paint on the face and then when it starts. This kind of attitude is in civilizations rather than being part of the savagery. Though they are right in their explanation, I guess they ignore the acts of the boys who let the fire out during their hunt dance. This symbol stands for the civilized dream of Ralph who wants to rescue them with the help of this fire. Now the development of their chant and reenactment of the pig killing takes place. From this point, it becomes crystal-clear that Golding is depending on the stereotyping of the evil and ignoring the civilization. Golding fails here to show that evil exists in the hearts of White people because he changes his English boys first in the guise of barbaric people and then lets them act brutally. He considers that white people cannot act like those barbaric living in Africa or India. He can be placed among those writers who are highly criticized for this act by Edward Said.

Lord of the Flies essentialities and naturalizes human behavior, especially (male) violence. Golding describes: "The moral is that the shape of society must depend on the ethical nature of the individual and not on any political system however apparently logical or respectable. The whole book is symbolic" (Golding 1952, p. 204). Suzanne Sunday (2005) critiqued studies that assume that biological factors determine aggression. This kind of attitude completely advocates the concept that all human actions and particularly aggressive ones are determined by genes. Thus, the view that aggression is not just dependent on human genes repels the concept that has been put forward by Golding in his novel. There is also another sociological and environmental factor responsible for aggressive behavior. It would be a very limited view of human nature when their behaviors specifically the aggressive ones are to be ascribed to the genetic factors only. There are clear possibilities and chances of other factors responsible or acting as stimuli for human actions as has been discussed in the abovementioned excerpt of Sunday. It is also one of the assumptions of Golding's aggression and the lust for power are inherently powerful forces that may bring us closer to savagery. However, Jackson Katz (1995) postulates that the aggression in man is not due to biological reasons rather these are determined by the ideology that a man holds. It is based on the idea that a man is prone to aggressive behavior. This has not only been in the old civilizations rather it has also been the part of the most recent civilizations where human consciousness at the general level is thought to have developed a lot. Golding does not take into consideration that the aggression in the boys can also be due to other factors rather than just the inherent nature of man (Al-Zamili, 2015). Although, Golding takes up a very pertinent philosophical and ethical issue in the novel. But had it been just across the board and presented at the universal human level, it could have applied to all human beings without getting involved in the debates of colonization and conflicts among human races. But there are clear indications that the story tells more than just the universal human condition of man on this planet. It also engages the readers in a dialogue that centers around the concepts like androcentrism, ethnocentrism, and its reliance on biological determinism. However, beyond any doubt, this story could be termed as important criticism on the European children and their behavior but at the same time, there are clear demarcations between the white and the colored races. This kind of criticism is also lacking in the movies that have been made on this story for in those movies the white race is shown as brave and powerful that can overcome the fears of evil, appoint lacking in the novel.

It can be, thus, interpreted that the novel is a colonized description and propagation of the blacks as well as the whites. The whites signifying good and abhorrence of evil while the blacks are represented as suggesting evil and darkness. Even the very act of speaking through the conch is initiated by the white who again expands the differences between good and evil. Golding has tried to strike the balance between good and evil as being equally inherent in all human beings, but the moment there is a grouping among the boys, it shows that evil is predominant in a specific colored group. Even the rescuing party belongs to the whites which again substantiates the imperialistic designs and white supremacy. So, this novel is not about the universal description of human nature, rather it is more Eurocentric and a focused picture of the two different races. The same has also been presented in the visual representation of the novel through movies. Positioning good and evil in the biological and genetic aspects of a particular group is also an act of labeling which is an even darker 
picture of the specific race. Rather than presenting a savage aspect of human nature, the novelist seems to hide behind the children and point to the blacks for their inherent flaws which can never be overcome except through the forces of the whites.

\section{Conclusion}

William Golding, who was writing his novel Lord of the Flies as a critique of human nature, seemed to fail in accomplishing his mission. He wanted to prove that all human beings are inherited with evil in their instincts (Syed, 2020). His novel fails to be a perfect critique of human nature on the four grounds. He has taken only boys for his characters thus ignoring the female population. This is his androcentric attitude, which causes his failure in accomplishing his task. His marooned boys are only English, thus showing that an ethnocentric attitude towards other races. He wants to show that what is true of the English people will be true about the nature of human beings. He also affiliates savagery with blacks, thus stereotyping barbarism, which fails his critique. He does not take the cause of the conflict from economic or political traditions but goes on to explain that all the conflicts are the result of biological characteristics. Thus, all these points prove that his critique of human nature is a failure.

\section{References}

Al-Zamili, A. (2015). Instinct or society? a Rouseauist analysis of corruption in William Golding's Lord of the flies. International Letters of Social and Humanistic Sciences, 58, 155-158.

Ballantyne, R. M. (1857). The Coral Island. T. Nelson \& Sons.

Belsey, K. (2005). Textual analysis. In Gabriel Griffin (Ed), Research Methods for Literary Studies (pp. 157-175). Edinburgh University Press.

Belsey, C. \& Moore, J. (Eds). (1997). the Feminist Reader: Essays in Gender and the Politics of Literary Criticism. London: MacMillan Press Ltd.

Carey, J. (2012). William Golding: The Man Who Wrote Lord of the Flies. Faber \& Faber.

Eagleton, T. (1996). Working with Feminist Criticism. Cambridge: Blackwell Publishers, 1996.

Fetterley, J. (1986). "Reading about Reading: 'A Jury of Her Peers,' 'The Murders in the Rue Morgue,' and 'the Yellow Wallpaper." In Gender and Reading: Essays on Readers, Texts, and Contexts, edited by Elizabeth A. Flynn and Patrocinio P. Schweickart (pp. 147-64). Baltimore: Johns Hopkins University Press.

Golding, W. (1954). Lord of the Flies. Boston: Faber and Faber.

Hobbes, T. (1996). "Leviathan". In Law and Morality: Readings in Legal Philosophy, Eds. David Dyzenhaus\& Arthur Ripstein. Toronto: University of Toronto Press.

Hook, H. (director). (1990). Lord of the Flies. New York: Castle Rock Entertainment Inc.

Hubbard, R. (1982). Have only men evolved? In Biological woman-The convenient myth, ed. R. Hubbard, M.S. Henifin and B. Fried, 17-46. Cambridge, MA: Schenkman.

Hume, D. (1983). An Enquiry Concerning the Principles of Morals. Indianapolis: Hackett Publishing Company.

Johnston, A. (1980). Of Earth and darkness: The novels of William Golding. Columbia: University of Missouri Press.

Katz, J. (1995). "Advertising and the Construction of Violent White Masculinity". In Gender, Race, and Class in Media, edited by Gail Dines \& Jean M. Humez. Thousand Oakes: Sage Publications.

Kinkead-Weekes, M. \& Gregor, I. (1984). William Golding: A Critical Study. Boston: Faber and Faber.

Rahman, K. R. (1990). The Moral Vision of William Golding. Dhaka: University of Dhaka Press.

Ramanan, M. (1987). "Aspects of Lord of the Flies". In William Golding: An Indian Response. A collection of Critical Essays on the Fiction of William Golding, edited by Satyanarain Singh, Adapa Ramakrishna Rao \& TaquiAli Mirza. New Delhi: Arnold-Heinemann Publishers.

Seiter, E. (1995). "Different Children, Different Dreams: Racial Representation in Advertising." In Gender, Race, and Class in Media, edited by Gail Dines \& Jean M. Humez. Thousand Oakes: Sage Publications.

Spender, D. (1985). Man-made language. Routledge.

Sunday, S. (2005). Biological theories of animal aggression. In Genes and Gender On Peace, War, and Gender A Challenge to Genetic Explanations. New York: CUNY Press.

Syed, G. K. (2020). Students' Response to Participating in an International Project on Readers' Response to Lord of the Flies: Insights into Using Collaborative Teaching Techniques. Journal of Education and Educational Development, 7(1), 27-43. 